\title{
WTO DISCIPLINES AND FISHERIES SUBSIDIES - SHOULD THE "SCM AGREEMENT" BE MODIFIED?
}

\author{
Oliver Delvos*
}

\begin{abstract}
This article considers the negotiations on a possible modification of the World Trade Organization (WTO) Agreement on Subsidies and Countervailing Measures (SCM Agreement) in relation to fisheries subsidies. The mandate for these negotiations was given by the Doha Ministerial Declaration of 2001. The current WTO regulations are deficient in that many subsidies do not meet certain criteria of the SCM Agreement. This is mainly due to the current definition of a subsidy, the requirements for specificity and the inadequate categorisation of "red box" and "amber box" subsidies. In order to address fisheries subsidies adequately, this article contends that the SCM Agreement must be changed. The United States, the European Community, several developing countries and Japan are actively discussing this issue. After examining the different proposals, the best solution seems to be to find a common categorisation for fisheries subsidies and to identify those which lead to over-capacity and over-fishing. Such subsides should be prohibited and named in an illustrative list. Furthermore, subsidies which are not reported to the WTO should be actionable. Any country which has not fulfilled its notification duties would have the burden of proving that these subsidies are consistent with the SCM Agreement. Under new WTO rules, subsidies which are beneficial for the environment should be permitted, such as subsidies for the retirement of fishing licences, the retraining of fishers and the scrapping of old vessels.
\end{abstract}

\section{INTRODUCTION}

For nearly a decade, States, international organisations and other institutions have been negotiating the level of fish stocks and their on-going exploitation. Due to increasing demand for fish products, many States have modernised their fleets, which has resulted in over-capacity in vessels and over-exploitation of the global fish stock. ${ }^{1}$ Although the fisheries sector often

* Submitted as part of the LLM programme at Victoria University of Wellington.

1 Food and Agriculture Organization of the United Nations The State of World Fisheries and Aquaculture 2004 (Rome, 2004) 142, available at <http://www.fao.org > (last accessed 18 August 2006) [State of World Fisheries]. Another source for these figures is: Stefania Vannuccini Overview of Fish Production, 
experiences high losses, subsidisation is a common method to keep the fisheries industry in economic balance. ${ }^{2}$

At the Ministerial Conference in Doha in 2001, the World Trade Organization (WTO) agreed to conduct negotiations for special fisheries disciplines. ${ }^{3}$ There are many problems with the current version of the WTO Agreement on Subsidies and Countervailing Measures (SCM Agreement). ${ }^{4}$ To be prohibited, subsidies must be specific and must generally have a distorting effect on international trade. Normally, fisheries subsidies do not meet these criteria under the SCM Agreement. ${ }^{5}$ Therefore, the existing definition of a subsidy must be modified, as must the requirement for specificity. In addition, the categorisation of prohibited and actionable subsidies must be remodelled to cover fisheries subsidies, at least. This proposal is supported by the "Friends of Fish", who are also of the opinion that the fisheries sector has unique features that cannot be addressed by the existing rules. ${ }^{6}$ The opposite view is that special treatment of this sector would lead to a fragmentation of the SCM Agreement, and that national measures, such as management regimes, are more effective in that respect. ${ }^{7}$

The last view should not be supported. Obviously, national and international regulations are not in the position either to stop the subsidisation in this industrial sector or the exploitation of marine resources. In particular, the problems of over-capacity and over-fishing should be addressed by the new rules. In addition, some subsidies should be expressly permitted, to attach more value to environmental concerns. Permitted subsidies should include all governmental help for better research about natural resources and the reduction of fishing capacities. The current WTO rules, which are applicable to the fisheries sector, do not have such special provisions.

Utilization, Consumption and Trade (Rome, 2004), available at <http://www.fao.org $>$ (last accessed 18 August 2006).

2 Gary P Anderson and Bradnee Chambers (eds) Trade, Environment and the Millennium (2ed, United Nations University Press, Tokyo, 2001) 144.

3 WTO Ministerial Declaration at Ministerial Conference, Fourth Session (WT/MIN(01)/DEC/1, Doha, 2001) para 28 [Ministerial Declaration].

4 Agreement on Subsidies and Countervailing Measures (15 April 1994) 1867 UNTS 14 [SCM Agreement].

5 Seung Wha Chang "WTO Disciplines on Fisheries Subsidies: A Historic Step Towards Sustainability?" (2003) 6 J Int'l Econ L 879, 885.

6 WTO Negotiating Group on Rules The Doha Mandate to Address Fisheries Subsidies: Issues, Submission from Australia, Chile, Ecuador, Iceland, New Zealand, Peru, Philippines and the United States (TN/RL/W/3, Geneva, 2002) paras 12-16 [The Doha Mandate]. Australia, Chile, Ecuador, Iceland, New Zealand, Peru, Philippines and the United States are named as the "Friends of Fish" because in the WTO Negotiation Group on Rules these countries submitted their views together. Their common aim is to establish stricter fishing rules. Many authors use this term instead of naming each country.

7 WTO Negotiating Group on Rules Japan's Basic Position on the Fisheries Subsidies Issue (TN/RL/W/11, Geneva, 2002) paras 2-5 [Japan's Basic Position]. 
In sum, the SCM Agreement must be modified to deal with fisheries more efficiently - on the one hand, to make prohibition less problematic, and on the other hand, to give governments a legal basis to invest in environmentally helpful programmes. Part II of this article will mainly examine the current situation in regard to fisheries subsidies. Part III is concerned with the ongoing negotiations. Part IV seeks an answer to the question of what should be done to address the existing deficiencies of the WTO rules on subsidies.

\section{FISHERIES AND THE WTO}

\section{A The SCM Agreement}

The origins of the current SCM Agreement are articles VI and XVI of the General Agreement on Tariffs and Trade (GATT) $1947 .{ }^{8}$ Later, in 1979, these provisions were summarised as the Subsidies Code of 1979 during the Tokyo Round. The present version of the SCM Agreement was formed under the Uruguay Round negotiations in $1994 .{ }^{9}$

The contemporary SCM Agreement uses a so-called "traffic light" approach to classify subsidies. That means that subsidies are categorised in three parts as prohibited ("red box" subsidy), actionable ("amber box" subsidy) and permitted ("green box" subsidy). The last category of subsidies under part IV of the SCM Agreement, which contains provisions for permitted subsidies, no longer has any legal effect because its applicability expired at the end of $1999 .{ }^{10}$

For the provisions of the SCM Agreement to apply, the requirements of article 1 and article 2 of the SCM Agreement have to be fulfilled. That means that any governmental aid must meet the criterion of a subsidy under this agreement, which includes the direct transfer of funds, goods and services. ${ }^{11}$ This also includes the case where a government does not demand revenues, such as taxes, that it is originally obliged to collect. ${ }^{12}$ Furthermore, a subsidy shall be deemed to exist if there is any form of income or price support in the sense of article XVI of GATT $1994 .{ }^{13}$ Importantly, it is required that a "benefit is thereby conferred". ${ }^{14}$ If this requirement is not fulfilled, payments can be granted, with their setting a subsidy under the WTO rules.

8 General Agreement on Tariffs and Trade (30 October 1947) 55 UNTS 187, arts VI and XVI.

9 Andreas Lowenfeld International Economic Law (Oxford University Press, Oxford, 2002) 234.

10 SCM Agreement, above $\mathrm{n} 4$, art 2.1(c)

11 SCM Agreement, above n 4, arts 1.1(a)(1)(i) and 1.1(a)(1)(iii).

12 SCM Agreement, above n 4, art 1.1(a)(1)(ii).

13 SCM Agreement, above n 4, art 1.1(a)(2); General Agreement on Tariffs and Trade (15 April 1994) 1867 UNTS 187.

14 SCM Agreement, above n 4, art 1.1(b). 
Besides these requirements, a subsidy must also meet the criterion of specificity under article 2 of the SCM Agreement. This article mandates that a subsidy must be granted to a certain enterprise. ${ }^{15}$ If a subsidy does not meet this criterion there are other explicit circumstances under which specificity can be assumed. ${ }^{16}$

As already stated above, subsidies under the SCM Agreement are allocated to two different boxes: the "red box" and the "amber box". The first category comprises all subsidies that are prohibited under article 3 of the SCM Agreement. These are subsidies that are contingent on export performance, and can also be deemed to be having an effect on export performance if they are "in fact tied to actual or anticipated exportation or export earnings". ${ }^{17}$ Annex I has an "Illustrative List of Export Subsidies" that fall under this regulation. Besides that, subsidies are prohibited if they are contingent upon the use of domestic goods over imported goods. ${ }^{18}$

"Amber box" subsidies or actionable subsidies are those that cause injury to the domestic industry of another member country or cause "serious prejudice" to the interests of another member. ${ }^{19}$ These injuries are summarised as "adverse effects". ${ }^{20}$ "Serious prejudice" in the sense of article 5(c) of the SCM Agreement is defined in article 6.3 of the SCM Agreement. ${ }^{21}$

15 SCM Agreement, above n 4, art 2.1(a).

16 Article 2.1(c) of the SCM Agreement, above n 4, states such factors, which are: "the use of a subsidy programme by a limited number of certain enterprises, predominant use by certain enterprises, the granting of disproportionately large amounts of subsidy to certain enterprises, and the manner in which discretion has been exercised by the granting authority in the decision to grant a subsidy. ... Account shall be taken of the extent of diversification of economic activities within the jurisdiction of the granting authority, as well as of the length of time during which the subsidy programme has been in operation."

17 Mitsuo Matsushita, Thomas J Schoenbaum and Petros C Mavroidis The World Trade Organization: Law, Practice and Policy (Oxford University Press, Oxford, 2003) 273.

18 SCM Agreement, above n 4, art 3.1(b).

19 SCM Agreement, above n 4, art 5(c).

20 SCM Agreement, above n 4, art 5(a).

21 Until the end of 1999, article 6.1 of the SCM Agreement, above n 4, contained four circumstances under which a "serious prejudice" was deemed to exist. Today, article 6.3 states the following:

Serious prejudice in the sense of paragraph (c) of article 5 may arise in any case where one or several of the following apply:

(a) the effect of the subsidy is to displace or impede the imports of a like product of another Member into the market of the subsidizing Member;

(b) the effect of the subsidy is to displace or impede the exports of a like product of another Member from a third country market; 


\section{B Scope of Fishery Production and Trade}

Before focussing on the issue of subsidisation, it is important to consider the facts and figures of fish production and trade. It is only once this data is considered that the extent of the subsidisation becomes obvious. In order to comprehend the opinions of the different nations on the issue, their role, especially those of developing countries, in global production and trade should be looked at.

\section{Production of fish commodities 22}

Since 1999, global fish production has been nearly stable with about 130 million tonnes being produced annually. In 2003 the overall production was 132.2 million tonnes, of which 90.3 million tonnes came from the catch of fish, and 41.9 million tonnes were produced by aquaculture. China, even as a developing country, is by far the largest producer. In 2002 China caught 16.6 million tonnes of fish. Peru is the next largest producer with half that amount in that year. The United States follows with 4.9 million tonnes, Indonesia with 4.5 million tonnes and Japan with 4.4 million tonnes.

\section{Aspects of international trade}

The international trade in fisheries commodities is split up between several nations. In 2002 global exports of fishery products were valued at US\$ 58.2 billion. In terms of quantity, exports in fisheries commodities were 50 million tonnes, which means that less than half of the total production of 133 million tonnes was exported. ${ }^{23}$ Developing countries have a market share of about 49 per cent of exports by value and 55 per cent by quantity. ${ }^{24}$ Again, China has the biggest market share of the export of fish commodities. In 2002 its exports had a value of US\$ 4.5 billion. Second is Thailand with US\$ 3.7 billion. Following closely are Norway, the United States and Canada. ${ }^{25}$

Importing nations of fish commodities are mainly industrialised countries. Japan is the largest importer of fish products, with a value of about US\$ 13.6 billion in 2002. The United States imported products worth US\$ 10 billion. The third greatest importing nation is Spain, followed by

(c) the effect of the subsidy is a significant price undercutting by the subsidized product as compared with the price of a like product of another Member in the same market or significant price suppression, price depression or lost sales in the same market;

(d) the effect of the subsidy is an increase in the world market share of the subsidizing Member in a particular subsidized primary product or commodity as compared to the average share it had during the previous period of three years and this increase follows a consistent trend over a period when subsidies have been granted.

22 Vannuccini, above n 1, 2-12.

23 State of World Fisheries, above n 1, part I 43.

24 State of World Fisheries, above n 1, part I 49.

25 Vannuccini, above n 1, 11. 
France, Italy and Germany. Each of these countries imported fish products with a value of about US\$ 3 billion. ${ }^{26}$

In sum, developing countries have the greatest market share in world production. The same conclusion can be drawn regarding world exports. In these two categories, China is by far the leading nation. The import sector shows another aspect. Here, Japan, the United States and the European Union are the biggest importers of fishery products.

\section{The Nature of the Problem}

The production and trade situation in the fisheries sector should not lead to the assumption that the sector is a lucrative business. In fact, the fisheries industry is highly unprofitable. Therefore, subsidisation is a common method in many countries to keep the industry in economic balance. The extensive subsidisation is a good indication that the existing rules on subsidies do not target the fisheries sector in a satisfactory way, otherwise such huge amounts could not be granted without significant WTO proceedings.

\section{Fisheries subsidies}

It is estimated that, on a global scale, the industry needs US\$ 54 billion of subsidies annually to break even. ${ }^{27}$ It is difficult to find precise data about the payments that this sector receives. The lack of reported data leads to the assumption that governments are very reluctant to publish official material about this issue. Of reported nations, Japan subsidises its industry the most heavily, with US\$ 2.2 billion in 1988. The European Union follows with US\$ 1.2 billion and the United States with about US\$ 1 billion. ${ }^{28}$

These figures are relatively old. Principally, the data can only be estimated or calculated from the data of revenue of the sale of fish products and the estimated annual operating and capital costs. The "deficit" between these two figures must then be filled with subsidies to establish an economic balance. $^{29}$

In 1998 Matteo Milazzo, a member of the United States National Marine Service, published an article that tried to calculate fisheries subsidies on more recently published data. He estimates that the fisheries sector receives US\$ 15 to US\$ 20 billion annually worldwide. ${ }^{30}$ It is significant that the

26 Vannuccini, above n 1, 11.

27 Hakan Nordstrom and Scott Vaughan Trade and Environment - WTO Special Studies 4 (WTO, Geneva, 1999) 24 .

28 WTO Committee on Trade and Environment Analysis on the Relationship between Fisheries Subsidies and Over-Exploitation of Fisheries Resources - Submissions from Japan (TN/RL/W/159, Geneva, 2004) 6.

29 Anderson and Chambers, above n 2, 146.

30 Matteo Millazzo Subsidies in World Fisheries: A Re-examination (Technical paper No 406, World Bank, 1998) 74 . 
author only considers environmentally harmful subsidies. ${ }^{31}$ Again, these figures are estimated and only a specific sector of subsidisation programmes was considered. Furthermore, it is not possible to find accurate data about subsidisation programmes in China, which is the most relevant producer and exporter in this industry. All in all, sufficient and satisfying data concerning fish stock depletion linked with subvention programmes is missing. ${ }^{32}$

Another reason for the circuitous applicability of the SCM Agreement is that there is no consensus of what a subsidy in the fisheries sector actually is. A common categorisation is missing. Comparing different approaches about the general categorisation of subsidies, ${ }^{33}$ it seems that the United Nations Environment Programme (UNEP) ${ }^{34}$ has prepared the most balanced solution. This is because it focuses not only on classical governmental aids such as contributions to incomes or prices, but it also refers expressly to subsidies that are very specific to the fisheries sector, such as the granting of access to foreign countries, waters and management subsidies. Furthermore, it is the most recently published article on the topic and was not written according to existing international definitions on subsidies.

Summarising the categorisation of the UNEP, there are eight basic kinds of subsidies that are granted to the fishery industry: ${ }^{35}$

(1) Subsidies to fisheries infrastructure;

(2) Management and research subsidies;

(3) Payments for access to foreign countries' waters;

(4) Subsidies for the permanent withdrawal of fishing vessels, permits and licenses;

(5) Subsidies to capital costs;

31 Millazzo, above n 30, 74.

32 Roman Grynberg and Natallie Rochester "The Emerging Architecture of a World Trade Organization Fisheries Subsidies Agreement and the Interests of Developing Coastal States" (2005) 39 JWT 503, 505.

33 Other studies concerned with the categorisation come from the Asia-Pacific Economic Corporation (APEC) Study into the Nature and Extent of Subsidies in the Fisheries Sector of APEC Member Economies (2000) 6$7<$ http://www.apec.org > (last accessed 15 August 2006); and the Organisation for Economic Co-operation and Development (OECD) and the Food and Agriculture Organization of the United Nations (FAO), cited in WTO Negotiating Group on Rules Subsidies in the Fisheries Sector: Possible Categorization, Submission from Argentina, Chile, Iceland, New Zealand, Norway and Peru (TN/RL/W/58, Geneva, 2003) para III.

34 Gareth Porter Analysing the Resource Impact on Fisheries Subsidies: A Matrix Approach (The UNEP Fisheries and the Environment Series, 2004) 5-11, available at UNEP <http://www.unep.ch $>$ (last accessed 15 August 2006).

35 Porter, above n 34, x. 
(6) Subsidies to variable costs;

(7) Subsidies to the income of employees; and

(8) Price support subsidies.

This categorisation covers all aspects which can lead to a benefit for the industry. However, there are also several difficulties. For example, the UNEP included all infrastructure aid by a government, which also includes payments for general infrastructure, such as the construction of highways to ports and other harbour facilities. ${ }^{36}$ It is doubtful whether such financial aid should be regarded as an explicit fishery subsidy even though it might be beneficial for that sector. ${ }^{37}$

The other categories address payments that are clearly related to the fisheries sector. Yet some questions remain open: for example, why has the UNEP included nearly all governmental payments for research and development programmes? Including management services such as marketing seems reasonable because the industry benefits from them. But some programmes do not benefit the industry, such as payments and assistance to protect certain marine areas and programmes for restocking. One might argue that in general these programmes are beneficial to the fishery industry as well, but it seems that one should make more distinctions between subsidies which are clearly beneficial for fishery enterprises, and research which is mainly done for the public interest. The other six categories cover payments offered to the industry in a direct way. These include payments to other governments to allow a country's fleets access to the domestic waters of another country. This is one of the most significant features that cannot be addressed with the existing WTO rules.

\section{Environmental impacts}

The international discussion about fisheries subsidies does not always result in the allegation that the subsidisation of this industry is affecting international trade. The more pertinent argument is that the massive subsidisation has lead to an over-capacity in the number of fishing vessels, which is often linked with the exploitation of the global fish stock. The following facts underline the need for improved international regulations.

It is a commonly known fact that the global fish stock is in danger. About 47 per cent of the major fish stocks are fully exploited and 18 per cent are exploited at an unsustainable level. ${ }^{38}$ Often, this fact is linked with subsidisation in the fisheries industry. Direct proof is hard to find, but it is a distinctive fact that where subsidies programmes have been expanded, fishing capacity has

36 Porter, above n 34,6

37 See Tracey M Price "Negotiating WTO Fisheries Subsidy Disciplines: Can Subsidy Transparency and Classification Provide the Means Towards and End to the Race for Fish?" (2005) 13 Tul J Int'l \& Comp L 141,170 , who is also critical that tax preferences and insurance are left out of the UNEP categorisation.

38 State of World Fisheries, above n 1, part II 86. 
increased, and that in the particular geographical area, the fish stock decreased rapidly. ${ }^{39}$ Some scholars are of the opinion that depletion commenced long before governments began subsidising their fishing fleets and that it will certainly continue after the subsidies end, as long as global population grows and demographic pressure exists. ${ }^{40}$

However, a recently published article by the UNEP comes to another conclusion. ${ }^{41}$ Following the findings in this article, five categories of fisheries subsidies are considered to be harmful to fish resources "under most real-world conditions": subsidies to infrastructure, subsidies to access foreign waters, subsidies to capital costs, subsidies to variable costs and subsidies which are granted as price supports. ${ }^{42}$ Subsidies to capital or operating costs and subsidies that contribute directly to an increased capacity of fishing vessels are described as the most harmful because they encourage vessel-owners to improve their fishing technologies even where there is no economic need for them to do so. ${ }^{43}$ A recent example of a harmful subsidisation is the fishing agreement between the European Union and Argentina. In the mid-1990s, the agreement allowed European fishermen to catch hake, squid and cod along the coast line of Argentina. For several years, about thirty subsidised vessels from the European Union harvested the fishing grounds. Within two years the population of hake had decreased by 33 per cent. ${ }^{44}$

But some categories are also described as "good subsidies" from an environmental perspective. Into this category might fall subsidies for the decommissioning of fishing vessels and management regimes to control and regulate fishing efforts. ${ }^{45}$

\section{Deficiencies in the SCM Agreement}

As will be illustrated, the need for change to the WTO rules cannot be over-emphasised. ${ }^{46}$ At present, the WTO has no special provisions that specifically address fisheries subsidies. The WTO

39 Chang, above n 5, 907. This effect occurs frequently when governments do not have management regimes or any catch quotas for fisheries. Japan is also of the opinion that ineffective management regimes are responsible for decreasing fish stocks: WTO Negotiating Group on Rules Fisheries Subsidies, the WTO and the Pacific Island Tuna Fisheries: Proposed Structure for the Discussion-Communication from Japan (WT/CTE/W/226, Geneva, 2004) paras 2-5.

40 Roman Grynberg and Martin Tsamenyi "Fisheries Subsidies, the WTO and the Pacific Island Tuna Fisheries" (1998) 32 JTL 127, 134.

41 Porter, above n 34, xi.

42 Porter, above n 34, 6.

43 Porter, above n 34, 32.

44 World Wildlife Fund Fisheries Subsidies and the World Trade Organization (Hong Kong, 1998) 1, available at $<$ http://www.wwf.org.hk $>$ (last accessed 18 August 2006).

45 Porter, above n 34, xii.

46 This view is supported by Price, above n 37, 146. 
Committee on Trade and Environment is currently the forum for discussions on this topic. Although the SCM Agreement is the relevant agreement that applies to the fisheries sector, it is claimed, especially by the "Friends of Fish", ${ }^{47}$ that the agreement in its current version is inadequate to stop fish depletion and the trade-distorting effects of subsidisation. The problem with fisheries subsidies is that this sector is unique. The main difference from the agricultural sector is that fish are a natural resource.

\section{The definition of a subsidy under article 1 of the SCM Agreement}

The first problem is that there is a lack of transparency. It has already been shown how difficult it is to find accurate figures about subsidies. Although the SCM Agreement has special rules in article 25 for the notification of subsidies, this system has generally not been effective in delivering reliable data on fisheries subsidies. Governments are apparently unwilling to notify their programmes to the WTO. ${ }^{48}$ Furthermore, it is a weak basis to start an action against another WTO member if their subsidisation programmes can only be estimated, or must be calculated from uncertain data material. Governments, especially China's, are very reluctant to publish any material on their subsidisation programmes. ${ }^{49}$

The deficiency lies within the definition of a subsidy under article 1 of the SCM Agreement. The current definition covers mainly direct subsidies. But, as described above, the actual subsidisation often takes place indirectly. ${ }^{50}$ An example could be access to the waters of a foreign country for domestic fishing fleets. Whether that is a subsidy in the sense of article 1 of the SCM Agreement is questionable. It could be argued that such a governmental agreement with another State might fall under article 1.1(a)(1)(iii) as a service, but this argument is barely supportable. For that reason, the term "service" appears too ambiguous. This might also be the explanation for why no WTO member has started an action against another WTO member under this article.

A further example of an implicit subsidy in the fisheries sector is a time limit set by a government for harvesting. For example, the Multilateral Environmental Agreement (MEA) prohibits the catching of certain fish species during spawning seasons. The non-enforcement of a law is therefore an implicit subsidy that is clearly not covered by the current SCM Agreement. ${ }^{51}$

47 The Doha Mandate, above n 6, paras 12-16.

48 Alice L Mattice "The Fisheries Subsidies Negotiations in the World Trade Organization: a 'Win-Win-Win' for Trade, the Environment and Sustainable Development" (2004) 34 Golden Gate UL Rev 573, 582.

49 This is despite an official website on fisheries <http:/www.china-fisheries.com> (last accessed 18 August 2006). The National Bureau of Statistics of China also does not provide any material $<$ http://www.stats.gov.cn> (last accessed 18 August 2006).

50 Chang, above n 5, 893 .

51 Chang, above $\mathrm{n} 5,895$. Another example that can constitute a subsidy is where a government is not collecting adequate fishing fees, in the form of taxes or other charges. Some argue that this falls under 
As examined above, there are also governmental programmes that are described as "good subsidies", such as payments for the retirement of fishing licences, the scrapping of vessels or the retraining of workers in the fisheries industry. Are these subsidies of the same nature as those defined in the SCM Agreement? This question cannot easily be answered. Under article 1.1 of the SCM Agreement such programmes have clearly a financial contribution. But where is the benefit? How should "benefit" be construed in this context? If the money is used for the decommissioning of old vessels, the benefit lies only in that the owner does not have to pay these charges. But what happens where the owner can then afford to buy a more efficient vessel? Another case occurs when the government pays for better research on fish stock, or pays for the construction of artificial reefs. Is there a benefit for the fisheries industry? These questions remain open, because in order to decide whether or not a benefit is conferred in the sense of the WTO rules the details and the circumstances must be considered closely.

\section{The requirement of specificity under article 2 of the SCM Agreement}

Besides the question regarding the definition of a subsidy in the fisheries sector, there are also many different opinions on the question of which governmental programmes meet the criteria of "specificity" under article 2 of the SCM Agreement. Article 2.1 states that a subsidy must be specific to "an enterprise or industry or group of enterprises or industries". Subsidies to those "certain enterprises" must fulfil the requirements of the following sub-paragraphs of the SCM Agreement. Some argue that the definition is so broadly defined that it covers most subsidisation programmes. ${ }^{52}$ Others argue that subsidising a whole industry is not "specific" because no particular sub-sector is explicitly addressed. ${ }^{53}$ Without going into more detail, there is no final conclusion on whether fisheries subsidies meet this criterion because, if a subsidy falls under the provisions of article 3 , the requirements of article 2 must not be fulfilled. ${ }^{54}$

\section{Prohibited subsidies under article 3 of the SCM Agreement}

After examining which kinds of subsidies are granted in the fisheries sector and whether they meet the criteria of a subsidy and specificity, it is even more important to look at the question of whether they can be considered as prohibited subsidies under article 3 of the SCM Agreement. Here, again, many problems arise because the requirements are that the subsidisation in the industry is, for the most part, not targeted to increase export performance. The reason behind the on-going

article 1.1(a)(1)(ii) as "revenue that is otherwise due is foregone or not collected". There has been no WTO dispute settlement case which has dealt specifically with this issue.

52 Christopher Stone "Too Many Fishing Boats, Too Few Fish: Can Trade Laws Trim Subsidies and Restore the Balance in Global Fisheries?" (1997) 24 ELQ 505, 515.

53 Chang, above n 5, 900 .

54 SCM Agreement, above n 4, art 2.3, states that any subsidy falling under the provisions of a prohibited subsidy under article 3 shall be deemed to be specific. 
subsidisation is to help the industry to conduct its business more efficiently, or even to exercise its business at all. Although the provisions do include subsidies that are also working as subsidies in fact rather than in law, ${ }^{55}$ it appears to be misguided to say generally that this is the case. Notwithstanding that fact, fisheries subsidies as categorised above do not fall under any paragraph in annex I of the SCM Agreement. The "red box" in its current version is, therefore, not able to deal with fisheries subsidies in a satisfactory way. The crucial factor is that a direct connection cannot be proven between governmental programs in this area and trade-distorting effects.

\section{Actionable subsidies under article 5 of the SCM Agreement}

The remaining area within the SCM Agreement is the "amber box", which contains provisions under which a subsidy is actionable. The discussion so far has shown how difficult it is to prove a linkage between subsidisation and trade distortion regarding export performance. It is doubtful that subsidies to general infrastructure, subsidies for management and research or "good subsidies" have adverse effects on the interests of another member by causing injury to its domestic industry. ${ }^{56}$ That the access to foreign countries' waters could cause injury to its domestic fishing industry is even less likely.

Subsidies to capital costs such as loan guarantees, subsidies to variable costs and subsidies to the income of employees will more likely fall under "actionable subsides" as well. It appears more reasonable to apply the provision of article 5(c), together with article 6.3 on fisheries subsidies, because the latter section sets out clear circumstances under which "serious prejudice" occurs. Because those provisions need not be directly linked with effects on world trade to be applicable, this category seems to be the most important in order to address fisheries subsidies. This view should be applied to article 6.3(c) in particular, because serious prejudice may arise when a subsidy has the effect of significant price undercutting. The problem here is that fish and fish products show a very large heterogeneity. For example, "hake" can be categorized according to 16 different species. Therefore, it is very complicated to prove which sort of "hake" is subsidised and which is not. Due to that diversity within the group of one animal species, the comparison between unsubsidised and subsidised prices is a problematic undertaking and a reference price is difficult to assess. ${ }^{57}$

55 SCM Agreement, above n 4, art 3.1(a).

56 In the sense of article 5(a) of the SCM Agreement.

57 This is based on an example given by New Zealand: WTO Negotiating Group on Rules Fisheries Subsidies: Limitations of existing subsidy disciplines, Submission from New Zealand (TN/RL/W/12, Geneva, 2002) paras 8-10 


\section{THE NEGOTIATION PROCESS}

\section{A The Call for Improvements}

Although pushed by major NGOs such as Greenpeace and the World Wildlife Fund, international regulations have failed to stop the massive subsidisation. In 1999, the Food and Agriculture Organization of the United Nations (FAO) tried to regulate and reduce the existing capacities in the fishing industry by establishing an "International Plan of Action for the Management of Fishing Capacities" (IPOA). ${ }^{58}$ This agreement is not legally binding on the FAO members. It attempts to reduce and eliminate all subsidies that are responsible for over-capacity in national fishery fleets. The fact that the IPOA does not deal with certain trade-related aspects and it is not legally binding makes it a weak instrument for the international task of regulating fisheries subsidies. Therefore, the WTO, with its several agreements, is the only international institution that has general and legally binding rules. ${ }^{59}$

This was also emphasised during the meeting of the United Nations Economic and Social Council's Committee on Sustainable Development in April 1999. The Committee concluded that the mere signing of international conventions is insufficient to stop the decline of fish resources. ${ }^{60}$ Additionally, it was held that there is an urgent need to stop illegal fishing. ${ }^{61}$

Since the Ministerial Conference in Doha in 2001, the WTO has put this issue on the official agenda for the current negotiations. The purpose of the negotiations is to "clarify and improve WTO disciplines on fisheries subsidies". ${ }^{6}$ In the last four years several nations have actively taken part in the negotiations, concerning whether and how the WTO rules on subsidies should be modified.

\section{B Changing the SCM Agreement - Statement of Nations}

The notion that the SCM Agreement must be reformed is shared by several governmental institutions. In brief, the United States and the European Union are the major supporters of a modification, whereas Japan is not entirely convinced that a change is needed.

58 Food and Agricultural Organisation of the United Nations "International Plan of Action for the Management of Fishing Capacity" < http://www.fao.org> (last accessed 18 August 2006)

59 Anderson and Chambers, above n 2, 150

60 UN Commission on Sustainable Development "Report on the Seventh Session" (1999) E/CN.17/1999/20, 14.

61 Nancy Nelson "International Concern for the Sustainability of the World's Fisheries: United Nations Efforts to Combat Over-Fishing and International Debate over State Fishing Subsidies" (1999) Colo J Int'l Envtl L \& Pol'y 157, 162 .

62 Ministerial Declaration, above n 3, para 28. 


\section{Supporters}

Even before the Doha Declaration was published in 2001, the United States submitted a statement that subsidies have their worst environmental effect in open-access fisheries ${ }^{63}$ and that trade distortions can easily be inferred. ${ }^{64}$

After 2001, the international discussion expanded. The "Friends of Fish" submitted an article that favours a modification of the SCM Agreement because "improved disciplines are required to address the exceptional and distinctive adverse effects arising from some fisheries sector subsidies." ${ }^{65}$ Shortly after that submission, New Zealand underlined its position by making a submission of its own on the issue, stating that the "main impacts of subsidies in the fisheries sector take the form of price suppression and price undercutting." 66

Likewise, the opinion of the European Community (EC) is that the SCM Agreement is inadequate to deal with the current situation in the fisheries sector. Though slightly more reluctant than other nations, the EC is of the opinion that the current SCM Agreement should be the basis for new disciplines. ${ }^{67}$

Interestingly, China mad just one submission concerning the current debate. ${ }^{68}$ In only one page, China presented a short list of subsidies that should be allowed. On the basis of that proposal, China could be said to be one of the group of nations that support a modification of the SCM Agreement, because the provisions of the old "green box", permitting subsidies, no longer exist. However, China is not an active member in pleading for an expanded "red box". Viewed in this way, it seems anomalous to include China along with the "Friends of Fish" and the EC as a supporter of a modified SCM Agreement. It is doubtful whether China would support harsher disciplines on fisheries, simply due to the fact that it is the largest producer of fish commodities. Therefore, China's position should be interpreted very carefully.

63 WTO Committee on Trade and Environment Environmentally-Harmful and Trade-Distorting Subsidies in Fisheries - Communication from the United States (WT/CTE/W/154, Geneva, 2000) para 9 [Communication from the United States].

64 Communication from the United States, above n 63, para 16.

The Doha Mandate, above n 6,1.

66 WTO Negotiating Group on Rules Fisheries Subsidies: Limitation of Existing Subsidy Disciplines Submission from New Zealand (TN/RL/W/12, Geneva, 2002) para 4.

67 WTO Negotiating Group on Rules Submission of the European Communities to the Negotiating Group on Rules - Fisheries Subsidies (TN/RL/W/82, Geneva, 2003) [Submission of the European Communities].

68 WTO Negotiating Group on Rules Proposal from the People's Republic of China on Fisheries Subsidies (TN/RL/W/9, Geneva, 2002) [Proposal from the People's Republic of China]. 


\section{Opponents}

The supporters include economically and politically important members. Nearly three entire continents, namely Europe, the United States and Australia, are demanding improved and special rules for the fisheries sector. Although the supporting side is very strong, the nations which are against any modifications to the SCM Agreement should not be underestimated. The leading nation is Japan. Playing a very active role in the Negotiating Group on Rules, Japan's argument is that the fisheries sector should not be treated separately from any other industrial sector. ${ }^{69}$ Further, it is argued that the current SCM Agreement is sufficient to address fisheries subsidies. Where those subsidies would distort international trade, the alleging country can take countervailing measures. Finally, Japan argues that management regimes under the United Nations Convention on the Law of the Sea (UNCLOS) are a more useful tool to achieve resource conservation. ${ }^{70}$ This last point is not supportable because the UNCLOS does not cover the protection of high seas fisheries. ${ }^{71}$

The Japanese view that there is no need to change the existing WTO rules is supported by the Republic of Korea. In its opinion, changing the existing rules would lead to a fragmentation of the current WTO system. ${ }^{72}$ The arguments about the heterogeneity of fish products and the supposed link between subsidisation and the depletion of fish stock are not convincing to them because the present research material does not prove the presumed link unequivocally. ${ }^{73}$

However, these two major players in international trade are not the only ones of the opinion that the SCM Agreement should be left untouched. In 2003 a statement by Antigua, Barbuda, Belize, Fiji, Guyana, the Maldives, Papua Guinea, Solomon Islands and St Kitts and Nevis was sent to the WTO with their concerns. These small coastal States are also against any modifications to the SCM Agreement, but come from a totally different foundation to that of Japan and the Republic of Korea. In their view, more restrictive rules on fisheries subsidies would have a negative effect on their economies. ${ }^{74}$ The argument is simple: as small coastal States, these countries do not have the capacity in fish vessels to harvest their own resources. Consequently, the governments of these

69 Japan's Basic Position, above n 7, para 2.

70 Japan's Basic Position, above n 7, para 20.

71 United Nations Convention on the Law of the Sea (10 December 1982) 1833 UNTS 3, part VII, s 1, art 8687 and s 2. In the latter section, article 116 and article 117 deal with fisheries. Article 116 assesses the right to fish on the high seas. Article 116(a) states that all States have the right for their nationals to engage in fishing on the high seas, subject to their treaty obligations. Article 117 assesses that all States have the duty to take, or to co-operate with other States in taking, measures for their respective nationals as may be necessary for the conservation of the living resources of the high seas.

72 WTO Negotiating Group on Rules Korea's Views on the Doha Development Agenda Discussions on Fisheries Subsidies (TN/RL/W/17, Geneva, 2002) para IV [Korea's Views on Fisheries Subsidies].

73 Korea's Views on Fisheries Subsidies, above n 72, para III.

74 WTO Negotiating Group on Rules Fisheries Subsidies (TN/RL/W/136, Geneva, 2003) para 3. 
States are beneficiaries of foreign payments that allow other fleets to enter their domestic waters. Furthermore, a prohibition on fisheries subsidies would destroy the system of small artisanal fisheries in their countries. Therefore, these developing coastal States would be disadvantaged by a modification of the SCM Agreement in two ways.

\section{Analysis}

The articles that have been submitted thus far contain very clear points. The United States and the European Community favour a modification, whereas Japan and the Republic of Korea are against such plans. The positions of developing countries are more diverse. Primarily, smaller countries are taking part in the discussion. Peru, Ecuador and the Philippines are members of the "Friends of Fish" as well as the United States, and are therefore supporters of new WTO rules. Other developing countries, such as the small coastal States, are following other interests and do not support the initiative of the Doha Declaration.

In order to understand the position of the other nations, it is useful to examine in detail which new provisions they believe should be inserted into the SCM Agreement. At this stage it is difficult to comprehend the specific intentions. Japan seems to be against any modification, simply judging by the fact that Japan is heavily subsidising its fisheries sector. But the United States and the EC are also subsidising their fisheries industries with billions of dollars. This attitude seems contradictory. Why do they want to change the SCM Agreement and in which way? An examination of the different approaches might help answer this question.

\section{POSSIBLE MODIFICATIONS}

\section{A Modification of the SCM Agreement}

Opinions differ on whether the SCM Agreement should be changed. It is not surprising that opinions on how the WTO provisions should be changed differ as well. Most of the suggestions come from the submissions of the different nations. Comments from academics are rare and mainly deal with the extent to which the WTO is the right forum for the discussion. The sources for new proposals are consequently the statements made in the Negotiating Group on Rules.

\section{Prohibited subsidies}

The extension of prohibited subsidies that are covered by article 3 of the SCM Agreement, the "red box", is the key to stopping subsidisation, but at the same time it is the most controversial category. The United States made the first step in the international discussion and proposed that the "red box" should prohibit all subsidies that "directly promote over-capacity and over-fishing, or have other direct trade distorting effects. ${ }^{175}$ This is a very rigorous approach and is therefore known

75 WTO Negotiating Group on Rules Possible Approaches to Improved Disciplines on Fisheries Subsidies, Communication from the United States (TN/RL/W/77, Geneva, 2003) para 5 [Possible Approaches - United States]. 
as the "broad ban" approach, because it tries to cover all programmes that are estimated to encourage over-capacity or over-fishing.

Shortly after that submission, the EC, as another major player in international trade, presented its views. In its opinion, new rules should also be based on the current rules of the SCM Agreement. The EC itself does not favour as restrictive an approach as the United States. ${ }^{76}$ Instead of giving a new formulation for the category, the EC lists subsidies that should not be allowed in the fisheries sector. These are capacity-enhancing subsidies, such as subsidies for the renewal of fishing fleets (like the construction of new vessels) and subsidies for the "permanent transfer of fishing vessels to third world countries." 77

Chile, also not concurring with the "Friends of Fish", supports the idea of banning all subsidies that promote over-capacity and over-fishing. These subsidies are summarised in their submission as subsidies of a "commercial nature". ${ }^{78}$ According to their submission, subsidies of a commercial nature are all subsidies that lower costs, increase revenues and can raise production. ${ }^{79}$ Six explicit examples are given. ${ }^{80}$ In their first submission, in April 2004 following the Ministerial Conference in Cancún, New Zealand followed the opinions of the United States and Chile. Prohibition was their primary principle as well, although the terms of over-capacity and over-fishing were more balanced. ${ }^{81}$

76 In fact, no statement is made regarding the "broad ban" approach. It is not even mentioned at all.

77 Submission of the European Communities, above n 67, para 4(i).

78 WTO Negotiating Group on Rules Possible Approaches to Improve Disciplines on Fisheries Subsidies, Communication from Chile (TN/RL/W/115, Geneva, 2003) para 8 [Possible Approaches - Chile].

79 Possible Approaches - Chile, above n 78, para 8(i).

80 Possible Approaches - Chile, above n 78, para 8(i) 1.3, states:

1. Subsidies designed to transfer a country's ships for operation on the high seas or in the local waters of a third country.

2. Subsidies that contribute to the purchase of ships, whether new or used.

3. Subsidies to help modernize an existing fleet.

4. Subsidies that contribute to reducing the costs of production factors.

5. Subsidies that generate positive discrimination in the tax treatment of the economic activity of operators involved in the capture, processing and/or marketing of fisheries resources.

6. Subsidies that result in positive discrimination in access to credit.

81 WTO Negotiating Group on Rules Fisheries Subsidies: Over-capacity and Overexploitation, Communication from New Zealand (TN/RL/W/154, Geneva, 2004) para 2 [Fisheries Subsidies: Overcapacity and Overexploitation]. 
So far, the positions seem clear that the "red box" should be expanded widely to address as many subsidies that are promoting over-capacity and over-fishing as possible. As these are very flexible terms, it is advisable to define what over-capacity means and when subsidies actually lead to over-fishing. "Over-capacity" could be explained as the capacity of a national fleet which exceeds the size that is actually needed for an economically healthy fishery sector. But what institution could decide when a certain State has an over-capacity in fishing vessels? How can a reasonable capacity be calculated? The same questions occur when the term "over-fishing" is used. When does this happen? These terms seem to be too ambiguous to result in the achieved goal of prohibition. It is doubtful that these terms will be interpreted and construed in the same way by all WTO members.

\section{Actionable subsidies}

In addition to suggesting the modification and expansion of the "red box" category, the United States made a very interesting proposal for the "amber box". In its opinion all subsidies that are presumed to promote over-capacity and over-fishing should be categorised in a so-called "dark amber box". ${ }^{82}$ The burden of proof would than be shifted to the accused member which would subsequently have to show that the assertions are not in accordance with the truth. Until the end of 1999, article 6.1 of the SCM Agreement had such a system, but this category was not renewed. ${ }^{83}$ The proposal of the United States focuses on the old provision and suggests that the "dark amber box" for fisheries subsidies could be modelled in accordance with that.

Chile proposed to use the "amber box" as the category for all subsidies which were not sufficiently notified to the WTO under article 25 of the SCM Agreement. In such a case, the member would be under an obligation to show to the complaining member that the subsidy has no trade-distorting effect. ${ }^{84}$

The proposals have one important thing in common, which is that the burden of proof is given to the defending member to show that certain accusations of subsidisation are not true. Again, the approach of the United States is very rigorous. The Chilean proposal appears reasonable because non-compliance with current WTO rules could then effectively be enforced. It is doubtful whether accusing another country of having subsidies that are presumed to promote over-capacity and overfishing, and that therefore the country in question should have to justify its governmental proceedings, would be either a useful or reasonable instrument. In summary, proposals for the modification for the "amber box" are very rare and play only a minor role in the current negotiations. Beside the discussion regarding prohibited subsidies, there are also a lot of suggestions as to which subsidies should be permitted.

82 Possible Approaches - United States, above n 75, para 6.

83 See above $\mathrm{n} 21$.

84 Possible Approaches - Chile, above n 75, para 8(ii) 1.4. 


\section{Permitted subsidies}

In order to give governments a limited scope to support environmentally helpful programmes, certain categories of subsidies must not be actionable or prohibited. The SCM Agreement, in its original version, contained provisions that addressed permitted subsidies. These provisions expired and since then subsidies have only been categorised as prohibited or actionable ones. After China demanded that subsidies for infrastructure construction and scientific research should be allowed, ${ }^{85}$ the submission of the EC in $2003^{86}$ started the debate of whether certain subsidies should be expressly permitted. The EC contended that subsides for the retraining of fishers, the modernisation of fishing vessels for safety reasons and subsidies for the scrapping of old vessels should be allowed in a modified SCM Agreement. ${ }^{87}$ In the case of incorporation, this proposal could also encourage workers and vessel owners to change their branch of business, which would result in less fishing and could function as an aid for setting up a business. Especially in structurally-lagging regions, the overall benefit would justify such payments.

Although not demanding the allowance of certain subsidies, the delegations of Antigua, Barbuda, Fiji, Guyana, Maldives, Papua New Guinea and the Solomon Islands want to exclude access fees and development assistance, as well as governmental aids for artisanal fisheries in small coastal States, from the definition of a subsidy in article 1 of the SCM Agreement. ${ }^{88}$ However, the exclusion of those subsides from the general definition would have the same result permitting them. New Zealand's first statement on the proposals for permitted subsidies argued that the implementation of a "green box" into the SCM Agreement would bear the risk of circumvention and therefore such suggestions should not be supported. ${ }^{89}$

In a submission in 2004, Japan presented an extensive list of subsidies to be considered as "green box" subsidies. ${ }^{90}$ At first sight, the list only covers areas that encourage the conservation and sustainable utilisation of maritime resources. The last-mentioned subsidy which should be regarded as "green box" is termed "protection of environment" and includes "the assistance for the

85 Proposal from the People's Republic of China, above n 68, para 3.

Submission of the European Communities, above n 67, para 1.

87 Submission of the European Communities, above n 67, para 4(ii).

88 Fisheries Subsidies, above n 74, para 3.

89 Fisheries Subsidies: Over-capacity and Overexploitation, above n 81, para 12.

90 WTO Negotiating Group on Rules Proposal on Fisheries Subsidies, Paper by Japan (TN/RL/W/164, Geneva, 2004) [Proposal on Fisheries Subsidies, Paper by Japan]. The content is surprising because at first Japan was against any modification of the SCM Agreement. Now, Japan participates actively in the discussion on how the existing rules should be modified. Due to that changed stance, one should not generally hold that Japan is favouring an absolute "no need" approach. See Marc Benitah "Ongoing WTO Negotiations on Fisheries Subsidies" (2004) The American Society of International Law $<$ http://www.asil.org $>$ (last accessed 18 August 2006). 
introduction of new technologies to reduce the by-catch of unintended small fish or untargeted species." ${ }^{91}$ Although fishing capacity should not increase, it is requested that those subsidies be allowed, even if the vessel itself enlarges in size. ${ }^{92}$ New Zealand, after an initial position against any permitted subsidies, proposed to exclude government expenditure on management frameworks from the "red box" under new WTO rules. Those services should focus on the management of fish stocks and ensure maximum yields for the future. ${ }^{93}$

Comparing all the suggestions for the "green box", common sense in the discussion supports the view that subsidies for the protection of the environment should expressly be permitted under modified WTO rules. As in the analysis of the suggestions for the "red box", it appears very difficult to come to a conclusion on which subsidies are environmentally helpful. "Management framework" is just one example of an ambiguous term. Although New Zealand is submitting an explanation, the formulation can bear the risk of circumvention. The changed stance of Japan towards the modification of the SCM Agreement should also be regarded with care. That subsidisation for the modernisation of fishing vessels should be allowed seems questionable, especially when the vessel may also enlarge in size.

\section{B Analysis}

The discussion principally deals with the "broad ban" approach. Supporters and opponents delivered several arguments for consideration. Leaving aside the argument that a special treatment of fisheries subsidies would lead to fragmentation, the question is how the huge variety of the special ways subsides are granted can be adequately addressed. The "broad ban" approach, suggested by the United States, is straightforward. Prohibiting all subsides which promote overcapacity and over-fishing is surely the right way to deal with the issue, but the terms should be clearer. A mechanism must be implemented that clarifies what over-capacity is and when fish stock is over-fished. The FAO could be the forum and organisation for such an achievement. Instead of clarifying these terms in the SCM Agreement, an illustrative list which contains all subsides that are covered by the "red box" should be added to the annex of the Agreement. The benefit would be that certain programmes would be clearly named as prohibited. However, it is nearly impossible to find a common categorisation of what fisheries subsidies actually are and what kinds should be added to that list.

91 Proposal on Fisheries Subsidies, Paper by Japan, above n 90, para 7.

92 Proposal on Fisheries Subsidies, Paper by Japan, above n 90, para 13. In 2005, Japan underlined its views in a joint article with the Republic of South Korea and Taiwan: WTO Negotiating Group on Rules Contribution to the Discussion on the Framework for the Disciplines on the Fisheries Subsidies, Communication from Japan, the Republic of Korea and the Separate Customs Territory of Taiwan (TN/RL/W/172, Geneva, 2005) para 14.

93 WTO Negotiating Group on Rules Fisheries Subsidies to Management Services, Article from New Zealand (TN/RL/GEN/36, Geneva, 23 March 2005) paras 4-5. 
With regards to actionable subsidies, the Chilean proposal ${ }^{94}$ to enforce the notification system of the SCM Agreement appears to be very useful in practice. If this suggestion were adopted, all subsidies would have to be notified to the WTO, which would lead to more transparency. Such a solution would also lead to more uniformity with the pre-existing rules. Each country acting in accordance with these new rules would not have to justify its own governmental programmes. It would give the responsibility to that country if it has to prove that its own subsidisation programmes are not harmful to international trade. The submission from the United States is more forthright because its approach is based on these assumptions. ${ }^{95}$ The defending country would have the burden of proof without any remedy, because the WTO or another country could just presume that a certain programme is inconsistent with international trade rules. Therefore, the idea from Chile should be supported. The suggestion for a "scoreboard" of all fisheries subsidies should also be adopted. ${ }^{96}$

The last issue which has to be discussed is how one should deal with the various demands for permitted subsides. Without a consensus on that specific question there is little opportunity to find a solution to which nearly every member can agree. Japan is a very active nation in the debate about the "green box". That is not surprising because Japan is the leading subsidiser. Due to that fact, a compromise has to be found with Japan.

On principle, all "good subsides" should be allowed because those subsides have an environmental benefit and are generally not harmful to international trade. The SCM Agreement could, therefore, permit subsidies for the scrapping of old vessels if it can be ensured that a new vessel is not bought with this financial help. Also, the retraining of fishers should be supported if these workers are switching to another business sector. Such subsidies should be permitted, because natural catastrophes are a "vis major" to the fisheries industry. For example, there was the sinking of the oil tanker Erika on the French Atlantic coast several years ago, or the Prestige at the north coast of Spain in 2002. A thousand kilometres of coastline were poisoned with oil. Nearly the whole fishery industry, as well as the aquaculture industry, suffered high losses or became insolvent. ${ }^{97}$

Subsidies which are used to modify fishing vessels should not be permitted, neither for reasons of safety nor for better fishing methods. The risk of circumvention is too great to justify an

94 Possible Approaches - Chile, above n 78, para 8.

95 Possible Approaches - United States, above n 75, para 5.

96 Such a scoreboard should name the category of the subsidy, the sector which is targeted, the purpose, and the amount of money which is granted. Additionally, a report about the possible impact on the environment could be submitted. Chile suggested the idea of a "scoreboard": Possible Approaches - Chile, above n 78, para 8.

97 Raul Garcia "The Prestige: One Year one, A Continuing Disaster" (2003) 19 World Wildlife Fund $<$ http://www.panda.org> (last accessed 18 August 2006); Maria do Carme Garcia Negro and Xoan Ramon Doldan Garcia "Economic Consequences of the Oil Spill Caused by the Prestige" (2003) 2 University of Santiago de Compostela <http://www.usc.es $>$ (last accessed 18 August 2006). 
allowance. The permission of management frameworks for research and development is questionable and difficult to decide on, but the benefits for the environment seem to be greater than the benefit for the industry, which could lead to trade distortion.

In this discussion, reference should also be made to the WTO Agreement on Agriculture. ${ }^{98}$ Article 13 contains a so-called "peace clause". WTO members have committed themselves to reduce domestic support and agriculture export subsidies, while at the same time members are allowed to pay subsidies within a certain scope. ${ }^{99}$ Annex II of the Agreement on Agriculture contains categories that are exempted from the support reduction commitments. In particular, article 2(a) of annex $\mathrm{II}^{100}$ could be a blueprint for a similar provision in the SCM Agreement in relation to fisheries subsidies. Annex II is also a "green box" and contains, besides the already-mentioned exemptions, economically neutral support such as retirement grants and aids to compensate for natural disasters. ${ }^{101}$ All other domestic subsidies deemed to have an impact on the markets have been classified as "yellow box". ${ }^{102}$

\section{CONCLUSION}

That there are general deficiencies in the SCM Agreement is not a new issue. Especially regarding the needs of developing countries, the common accusation seems to be that the types of subsidies used in developing countries are non-actionable, whereas those that are needed in developing countries have been left out of this special dispensation. ${ }^{103}$

The Ministerial Conference in Doha clearly expressed the wish not only to improve its disciplines on fisheries subsidies but also to take into "account the importance of this sector to developing countries." 104 This mainly targets small vulnerable coastal States and not the major

98 Agreement on Agriculture (15 April 1994) 1867 UNTS 410 [Agreement on Agriculture]. This Agreement also allocates subsidies to different boxes: green, yellow and blue. Due to this similarity with the SCM Agreement, a reference to these provisions seems reasonable.

99 David Morgan and Gavin Goth "Peace in our Time? An Analysis of the Agreement on Agriculture" (2003) 37 JWT 977, 984. It is important to note that the peace clause expired on 31 December 2003.

100 Agreement on Agriculture, above n 98, annex II, art 2(a), allows programmes for research, including general research, research in connection with environmental programmes, and research programmes relating to particular products.

101 Agreement on Agriculture, above n 98, annex II, arts 8-9.

102 Fabian Delcros "The Legal Status of Agriculture in the World Trade Organization: State of Play at the Start of Negotiations" (2002) 36 JWT 219. Beside these two categories, a "blue box" exists which has certain provisions regarding European support aids.

103 Bhagirath Lal Das The WTO Agreements: Deficiencies, Imbalances and Required Changes (Zed Books, London, 1998) 50.

104 Ministerial Declaration, above n 3, para 28. 
players like China, Chile, Peru or Thailand. Some people would "raise their eyebrows if one were to argue that countries such as China should be included in the definition of developing countries."105

Therefore, the question is how artisanal production can be protected. Should there be different treatment for those small States? Antigua, Fiji and Barbuda would definitely be the most disadvantaged WTO members under new disciplines. ${ }^{106}$ For example, one could think of exceptions for those countries such as adding them to the annex of article 27.2 of the SCM Agreement, which contains exceptions to the provisions of the "red box" for certain developing countries. ${ }^{107}$ As already mentioned, scholarly journals rarely address this topic. ${ }^{108}$ This might be due to the fact that the discussion is underway and a consensus is not foreseeable and difficult to predict.

The other important question is whether the WTO itself is the right institution for this issue. In the case of an incorporation of new subsidies rules and the notion of adverse environmental effects, this would be the first time the WTO has recognised adverse effects which are not based on international trade matters. ${ }^{109}$ If the WTO decides not to expand its responsibilities to that extent, the FAO could be the appropriate forum. Together with the United Nations, binding rules could be created to address the problem in the right way. Although the WTO is a trade-orientated organisation, it is incomprehensible why there should be provisions for the agricultural sector only and not for the fisheries sector. The negotiations under the "Uruguay Round reform programme for trade in agriculture" show that the deficiencies are not only in the fisheries sector. The negotiations in order to improve the Agreement on Agriculture indicate the same problems of a lack of

105 Surya P Subedi "The Road from Doha: the Issues for the Development Round of the WTO and the Future of International Trade" (2003) 52 ICLQ 425, 435.

106 See also Grynberg and Rochester, above n 32, 522 and 523 .

107 SCM Agreement, above n 4, article 27.2 provides that the prohibition of article 3(1)(a) does not apply to countries which are named in annex VII. This annex comprises:

(a) Least-developed countries designated as such by the United Nations which are Members of the WTO.

(b) Each of the following developing countries which are Members of the WTO shall be subject to the provisions which are applicable to other developing country Members according to paragraph 2(b) of article 27 when GNP per capita has reached \$1,000 per annum: Bolivia, Cameroon, Congo, Côte d'Ivoire, Dominican Republic, Egypt, Ghana, Guatemala, Guyana, India, Indonesia, Kenya, Morocco, Nicaragua, Nigeria, Pakistan, Philippines, Senegal, Sri Lanka and Zimbabwe.

108 Apart from the fact that only three or four articles really address this particular topic, textbooks, except Anderson and Chambers, above n 3, do not discuss this issue at all. The chief cause seems to be that all relevant texts were written prior to the Ministerial Conference in Doha in 2001.

109 Benitah, above n 90, 3 . 
notification and the on-going circumvention of the existing rules. ${ }^{110}$ Perhaps solutions can be transferred to a special fisheries agreement or the SCM Agreement in general. ${ }^{111}$

110 WTO "Agriculture: Explanation: Export Competition/Subsidies" <http://www.wto.org $>$ (last accessed 18 August 2006).

111 This article substantively reflects the state of the negotiations until July 2005. The international discussion has, however, further developed and several new submissions were made within the Negotiating Group on Rules. Now, Brazil and smaller Pacific States are taking actively part in this discussion. In December 2005, the issue of fisheries subsidies and a possible restructuring of the applicable agreements of the WTO were on the agenda of the Sixth Ministerial Conference in Hong Kong. Despite the fact that the discussion has been in progress for several years and has delivered different proposals to change the SCM Agreement, the Ministerial Declaration of 18 December 2005 does not include any decisions on the fisheries issue. Annex D of the declaration repeats the intention to clarify the existing rules but does shed any light on when a decision on the fisheries issue can be expected. See WTO Ministerial Declaration at Ministerial Conference, Sixth Session (WT/MIN(05)/DEC, Hong Kong, 2005) annex D. 